\title{
A Variety of Turkish in Mid-south Turkey: Arabic-Turkish Inter-language
}

\author{
Eser Ordem ${ }^{1}$, Erdogan Bada ${ }^{2}$ \\ ${ }^{1}$ Adana Science and Technology University, Turkey \\ ${ }^{2}$ Cukurova University, Turkey \\ Correspondence: Eser Ordem, Adana Science and Technology University, Turkey.
}

Received: August 24, 2016

doi:10.11114/jets.v5i1.1835
Accepted: September 27, $2016 \quad$ Online Published: November 24, 2016

URL: http://dx.doi.org/10.11114/jets.v5i1.1835

\begin{abstract}
Studies on inter-language in the second language acquisition field have been of paramount importance in recent years. In line with such studies, thus with this study we aim to show oral production samples of adult Arabic speakers of Turkish $(\mathrm{N}=10)$ through elicited data in natural conversation settings, and to analyze the data morphosyntactically and lexically based on the inter-language hypothesis. Analysis of the gathered data indicates that the participants produced the target language quite competently and fluently by showing morphosyntactic and lexical variations in their output. The results obtained from intralingual communication, where only Arabic speakers are involved, suggest that the variety in question displays relative variations from the standard dialect in two domains mentioned above. Findings concerning Arabic and non-Arabic speakers present a rather different picture in that the variety gets much closer to the standard Turkey Turkish, and tend to support literature review emphasizing the importance of inter-language variation from socio-ecological and socio-cultural viewpoints. The study implies that second language acquisition might be attained in adulthood.
\end{abstract}

Keywords: inter-language, variation, second language acquisition, Arabic, Turkish

\section{Introduction}

The dominance of Universal Grammar studies (Flynn, 1987; White, 1990; Cook, 1997; Trettenbrein, 2015) in second language acquisition has downgraded the importance of cultural, social and psychological factors in this field. These studies often emphasized the significance of biological factors for several decades resulting in lending support to merely children' effortless acquisition of first or second language. Adult learners, in this sense, have been perceived as insufficient, inaccessible to UG and incapable learners. Similarly, the studies of critical period hypothesis (Penfield \& Roberts, 1959; Lenneberg, 1967; Johnson and Newport, 1989; Slavoff \& Johnson, 1995) have often showed a positive linear correlation between age and language acquisition. The puberty has been perceived as the most critical period and factor while acquiring first or second language. Factors such as age, length of stay and processing difficulties have been prioritized. In these studies, a dichotomy between learning and acquisition has been viewed as a practical tool in that the former refers to conscious knowledge of a second language and the latter to subconscious process of rules (Krashen, 1982). However, in this study this distinction will not be taken into account.

Several factors such as loss of Universal Grammar, loss of neural plasticity, maladaptive gain of processing/memory capacity and the inhibitive effect of L1 on L2 have been put forward to explain the reasons for failing to attain near-native competence (Marionova-Todd, Marshall, \& Snow, 2000). However, various researchers have handled this second language acquisition (henceforth, SLA) issue in different ways by using the terms contrastive analysis (James 1980; Lado 1957), accessibility to universal grammar (White, 1990) inter-language (Selinker, 1972; Tarone, 1983), approximative system (Nemser,1971), idiosyncratic dialect (Corder, 1971), basic variety (Klein \& Perdue, 1997), pidginization (Schumann, 1978, 1986) and variation (Bayley, 1994). In this study, the term inter-language (therefore IL) is used in this study to refer to 'a separate linguistic system based on the observable output which results from a learner's attempted production of a target language norm' (Selinker 1972: 214). Another term that will be used is variation since the perspective of this study is not to unearth deviation, errors, mistakes or abnormalities. The term inter-language provides us with the opportunity to approach second language product as variation. Therefore, inter-language is quite a handy and practical term to reinforce our perspective towards SLA. Selinker's limited definition of inter-language was broadened by Adjemian's (1976) view of IL that regards ILs as natural languages. Similarly, Towell and Hawkins (1994) note that ILs can accept new rules and are open to changes. Meisel, Clahsen and 
Pienemann (1981) also maintain that ILs are also competitive and unstable.

IL variations generally refer to postpubescent/adult learners (Patkowski, 1990; Johnson and Newport, 1989). White and Genesee (1996) stated that postpubescent learners as well can attain native competence. In their seminal article, Marionova-Todd, Marshall and Snow (2000) focused on three misconceptions about age and L2 learning by showing contradictory studies about adult language learners. The bias towards adult language learners result from the generalization of several findings that are only in favor of children, and ignorance of successful and near-native adult learners. Marionova-Todd, Marshall and Snow (2000) showed that misattribution of some factors such as age and neurobiological capacity have led to misinterpretation and misemphasis of adult language learning. Although behavioristic and cognitive-based studies in SLA have been quite fruitful and incremental in the last several decades and helped researchers understand the problems in SLA, both movements have long perceived certain utterances of language learners as deficient, erratic and deviant. Therefore, socio-cultural (Van Lier, 2004), socio-cognitive (Atkinson, 2011; Lantolf, 2011) and socio-ecological views (Kramsch, 2002; Larsen-Freeman, 2002; Kramsch and Steffensen, 2007; Atkinson, 2011) have been ignored due to predominance of behaviorist and cognitive approaches although sociocultural theory of language theoretically and practically emerged in the 1960s and 1970s (Vygotsky, 1962; Hymes, 1972; Schumann, 1978). In contrast to behaviorist and cognitivist approaches tending to focus on errors and deviance of language learners - whether product or process-based - these approaches (viewed as an alternative to the first two movements) focus on actions, processes, particularities, constructions, situations, individual variability, interaction, adaptive behavior, embodied experience, nonlinearity, open and distributed system and soft assembly rather than on deviance, deficits, entities, objects, products, abstractness and universal principles. Another term developed for second language acquisition studies is Basic Variety (Klein \& Perdue, 1997). This term refers to development and learning of a well-structured, efficient and simple form. In this sense, Klein and Purdue (1997) ask a question that reverses the movement of language studies that aim to reach a final stage: Couldn't natural languages be much simpler? Their answer to this question is 'Yes but not very much' (p.40) because language learners organize their input according to the principles of innate structure. It means that utterances of language learners are 'well-structured, highly efficient and very simple' (p.40). Although it is believed that language learners develop efficient communication system called Basic Variety, we disagree that this variety is based on only innate language capacity. Rather, basic variety can be incorporated into socio-ecologocial domain which presupposes that grammar and meaning are emergent rather than a fixed stage that remains to reach a final stage for the sake of innate language capacity as a cognitive potential structure. Therefore, we adopt the tenets of basic variety and socio-ecological theory together. An objection might be raised about Basic Variety because in this study Arabic speakers of Turkish used quite a few complex sentences with some inflectional omissions. In this sense, adult learners may go beyond Basic Variety even if two languages are typologically distant from each other (Song, 2002; Marionova-Todd, Marshall, \& Snow, 2000).

According to these two theories, interaction and communication in a certain authentic community enable adults to acquire a second language. In this sense, language learning is grounded in authentic social settings. Most languages display some variations within themselves depending on their speakers' geographical location and/or language background. Within the variety employed are embedded the speakers' views of the outer world, behavior, manners, intra-/inter-social relations, ethnic and/or language background. Schumann (1978) notes that social-psychological factors such as distance and proximity affect the degree of language acquisition. Unlike biological factors, social proximity to the target culture called acculturation has a positive effect on the success of acquiring the target language. The situation gains a rather interesting aspect when the variety spoken is in contact with another variety of a totally distinct language background, as in the case of Turkish and Arabic. Since Arabic speakers of Turkish feel quite proximal to Turkish culture historically and culturally, they tend to develop a positive attitude towards learning Turkish language. This study aims to show morphosyntactic and lexical behavior of language acquisition in a natural environment and the transition from Arabic to Turkish in Turkey setting, and intends to indicate that SLA can take place at a late age (Gass, 2013).

\subsection{Research Questions}

The main aim of this study is to uncover the morphosyntactic and lexical production of adult Arabic speakers of Turkish in their natural settings. Within this framework, answers are sought for the following questions:

1. What specific constructions emerge in production of adult Arabic Speakers of Turkish?

2. What kind of lexical coinages appear in Arabic-Turkish inter-language?

3. What lexical collocations arise as a result of Arabic- Turkish contact?

\section{Methodology}

This research was designed as ethnographic and qualitative in nature (Whitehead, 2005; Bardovi-Harlig, 1999). 
Whitehead (2005:15) calls this design 'natural conversational ethnographic interview' and describes this process as 'informal and unstructured'. Accordingly, the speech data in this study was elicited via natural conversations. By doing so, the researchers placed their study participants into sociocultural contexts that are meaningful for them. This emic perspective provides a valid understanding of the socio-culturally rich linguistic context that is also important to the participants. This elicitation technique was selected for two reasons. First, the conversations were natural and productive since they contained authentic and lived experiences in their production. Second, these natural conversations provided rich linguistic data from simple structures and literal use of words to complex sentences and idiomatic expressions. In addition to the elicited data, the researcher also used another researcher's data (Özezen, 2013) obtained in the field to enrich the data and analysis.

\subsection{Participants}

The participants were composed of 10 females born in 1930-40s in the mid-south of Turkey and have been living in Turkey since their birth. The participants were late bilinguals who were totally illiterate with no explicit education at schools at all and that were exposed to Turkish between 6-8 hours daily. The age groups were 70-86. They reported that they learned Turkish from their children, grandchildren and media. The peers spoke Arabic among each other but Turkish with their grandchildren and outsiders from different ethnic backgrounds and recent generation. The daily language of the bilingual participants was recorded with a digital voice recorder. The data was transcribed by the researchers and collected only in natural settings (at their homes). The participants talked about daily topics such as their relations with the neighbors and relatives, history of the community, their daily routines and religious activities.

\subsection{Data Collection}

The researchers met each participant once a week for at least five hours a week. However, approximately one hour recording was able to be obtained in each session. The participants were recorded at an appropriate time while speaking spontaneously since each recording entailed a long warm up conversation with them. The study took 20 weeks to complete. The researchers did not guide the participants to talk about a certain subject. A 20-hour spoken data was collected. Although some raw observations regarding the target language were made before the study, it was not known what kind of specific constructions would be produced by the participants after the study.

\subsection{Data Analysis}

Qualitative data analysis is in nature iterative and non-linear (Dörnyei, 2007; Cresswell et.al., 2003). The data collected from the participants was qualitatively and quantitatively analyzed utilizing SPSS v.17. To analyze the qualitative data, the sentences uttered by the participants were recorded, and the canonical Turkish sentences were not transcribed. Therefore, partial transcription was used, and specific constructions, lexical coinages and novel lexical collocations were extracted from the data in accordance with the framework of the study. A general overview of the morphosyntactic structures was given. The average number of the sentences per minute was calculated. In addition, frequencies and per centages of specific constructions were given.

\section{Results}

The overall results showed that the participants reached native competency in linguistic areas except with some variations. Since the participants were all illiterate, no written standard tool was used to measure their level. However, they could produce complex sentences effortlessly in the target language. The participants produced Turkish idioms, collocations, formulaic language and complex sentences quite competently and fluently. Some variations were observed in the output.

\subsection{Production of Morphosyntactic Structures}

The data collected from the participants showed some variations when compared to their children and grandchildren who monolingually spoke standard Turkey Turkish. Since their grandchildren were raised in regular Turkish schools, they all speak standard Turkey Turkish. The participants tended to omit some inflections, and the word order intermittently differed from participant to participant. The number of the participants, average sentences per minute and in total uttered by Arabic speakers is given in Table 1.

Table 1. Participants and total sentences

\begin{tabular}{ll}
\hline & $\mathrm{N}$ \\
\hline Participants & 10 \\
Average sentence per minute & 20 \\
Average sentences uttered in total & 24000 \\
\hline
\end{tabular}


A general overview of variations in Standard Turkey Turkish and Turkish of Arabic speakers can be seen in Table 2.

Table 2. A general overview of sentences in Turkey Turkish and Turkish of Arabic Speakers

\begin{tabular}{|c|c|c|}
\hline & Standard Turkey Turkish & Turkish of Arabic Speakers \\
\hline Subject & Ben uyanmamışım & Ben uyanmamış \\
\hline pronoun & I sleep- Neg-past Evidential+ 1st sub pro & I sleep Neg-past Evidential $+\varnothing$ \\
\hline Adjective & Benim babam istedi. & Benim baba istedi \\
\hline Pronoun & ( My+Gen father+Poss want+past) & $M y+$ gen father $+\varnothing$ want+past \\
\hline \multirow[t]{2}{*}{ Past tense } & Terazi yoktu eskiden & Terazi yok eskiden \\
\hline & Scales exist+Past formerly & Scales exist $+\varnothing$ formerly \\
\hline \multirow[t]{2}{*}{ Different case } & Şimdi çalışıyor Ticaret Odasında & Şimdi çalışıyor Ticaret Odası \\
\hline & Now work+ Prog + Chamber of Trade+Loc & Now work + Prog Chamber of Trade $+\varnothing$ \\
\hline \multirow[t]{2}{*}{ Participle } & Babası öldüğü zaman 1 yaşında & Babası öldü zaman 1 yaşında \\
\hline & Father + Gen die + Past + Part time 1 year old & Father+Gen die + Past $+\varnothing+$ time 1 year old \\
\hline \multirow[t]{2}{*}{ Passive } & Elin kirıliyor & Elin kırıyor \\
\hline & Hand + Gen Break + Passive + Prog & Hand + Gen Break $+\varnothing+$ Prog \\
\hline \multirow{2}{*}{$\begin{array}{l}\text { Different } \\
\text { word order }\end{array}$} & Evde İngilizce konuşuyorlar & Konuşuyorlar İngilizce evde \\
\hline & Home + Loc English speak + Prog +3 pl & Speak + Prog $+3 \mathrm{pl}+$ English Home+Loc \\
\hline
\end{tabular}

The findings in Table 2 show that the participants developed seven morphosyntactic constructions. They omitted first subject pronoun suffix used in Turkey Turkish. Similarly, they also left out the suffix in the adjective pronoun. In addition, they did not use past tense suffix since they might have markedly used the past tense adverb. They also excluded the locative case. However, the context was meaningful even if they omitted the locative case since the sentence was contextually rich. Adverbial participle suffix was also dropped in the output. As for the passive construction, the passive suffix was not used. In terms of word order they tended to produce a different word order similar to the source language rather than the target language. While Turkey Turkish has Subject Object Verb canonical word order, Arabic has Subject Verb Object canonical word order. The number and frequency of these constructions are presented in Table 3.

Table 3. Specific Constructions of Turkish of Arabic Speakers

\begin{tabular}{llcc}
\hline \multicolumn{1}{c}{ Specific Constructions } & f & \% \\
\hline $\mathbf{1 .}$ & Subject pronoun omission & 320 & 1.33 \\
$\mathbf{2 .}$ & Sentences with adjective/possessive & 140 & 0.58 \\
& omission pronoun & & 0.47 \\
$\mathbf{3 .}$ & Sentences with different word order & 89 & 0.37 \\
$\mathbf{4 .}$ & Sentences with case omission/different case use & 42 & 0.17 \\
$\mathbf{5 .}$ & Sentences with past tense omission & 14 & 0.05 \\
$\mathbf{6 .}$ & Sentences with passive omission & 33 & 0.13 \\
$\mathbf{7 .}$ & Sentences with participle omission & & \\
\hline
\end{tabular}

The findings in Table 3 indicate that the participants produced various constructions not observed in the target language. Although they omitted some suffixes observed in the target language, these constructions did not hinder the pacing of communication. These omissions might be interpreted as variations since even the target language might show some variations dialectically or idiosyncratically. In addition to these morphosyntactic variations, certain lexical variations were also observed.

\subsection{Lexical Coinage}

Lexical coinage involves the process of creating words to be tailored to particular purposes as a possible result of contact occurring between two languages (Abdullahi-Idiagbon \& Olaniyi, 2011). The data collected by Özezen (2013) contained lexical coinage variations as well. Arabic speakers of Turkish conjugate Turkish words with Arabic inflections. This process can be evaluated as creative since a word in Turkish takes Arabic inflections. In their attempt to use only Arabic words, Arabic speakers employ Arabic inflections but when they prefer to use Turkish words, they often conjugate these Turkish words with Arabic inflections. In some cases, some Arabic words are conjugated with Turkish inflections.

The participants in this study used both the source and target language while producing Turkish verbs with Arabic suffixes in Table 4. This finding shows that the root verb was dominant in Turkish but suffixes were dominant in Arabic language. However, they could also use Turkish suffixes easily when needed, which shows that they have the ability to apply both Arabic and Turkish suffixes in verbs. In addition to these coinage variations, lexical collocational differences were noticed. 
Table 4. Conjugation of Turkish verbs with Arabic suffixes

\begin{tabular}{lll}
\hline Turkish verb & $\begin{array}{l}\text { Turkish verb root with Arabic } \\
\text { suffix }\end{array}$ & English \\
\hline 'annaş & 'annşäyt & agree \\
’ännät & 'ännäyt & say/tell \\
Daġgat & dag̈gääyt & distribute \\
Qällan & qällnäyt & use \\
Qannaq & qannqäyt & accommodate, settle \\
Qäzzän & qäzznäyt & win \\
Tämmäz & tämmzäyt & clean \\
Yassaq & yassqäyt & ban \\
\hline
\end{tabular}

\subsection{Novel Lexical Collocations Composed of Arabic and Turkish Words}

Lexical collocation can be defined as 'a relationship between lexical items that regularly co-occur' (Carter, 1998, p.163). Although Standard Arabic speakers can utter a sentence without a collocation, Arabic learners of Turkish created a novel collocational construction composed of Arabic verbs and Turkish nouns. The data was collected and presented by Özezen (2013).

Table 5. Arabic Verb + Turkish Noun collocations

\begin{tabular}{ll}
\hline Äxäd täqlîd(äh)/äxdäyt taq'lîd(äh) & Perform imitation \\
\hline säwwätaq'lîd(äh)/säwwäyt taq'lî̀d(äh) & Perform imitation \\
fäwwät 'käzä (qä'zäy) / fäwwtäyt 'käzä (qä'zäy) & Have an accident \\
säwwä taxmîn / säwwäyt taxmîn & Make a guess \\
şíriyb sîgärä (cîgärä, siggarāyy) & Smoke a cigarette \\
\hline
\end{tabular}

The participants created meaningful collocations by combining Arabic verbs with Turkish nouns as indicated in Table 5 . They could also produce Turkish collocations by replacing Arabic verbs with Turkish ones. In this sense, they showed alterations in producing verb +noun collocations. This finding shows that they are competent in using both languages while producing lexical collocations.

\section{Discussion}

The main aim of this study was to show that second language could be acquired at a later age with a separate linguistic system ending in variations (Freeman, 1997; Brown, 2000). Freeman (1997) and Brown (2000) note that since language acquisition does not proceed in a linear way but rather in a chaotic and entropic way, it may better to rid false dichotomies. Therefore, in this study the term acquisition rather than learning was used since the term learning could refer to a lesser role in SLA. In accordance with the claims of Marionova-Todd, Marshall and Snow (2000), a target language, albeit typologically different, might end in successful acquisition. When social settings are easily accessible and convenient for learners to acquire a target language, second language can be attained even if the adult speakers are illiterate and therefore have the only chance to acquire the target language orally. In this study, the adult learners produced the target language quite fluently by using not only quite a few regular grammatical structures but also idiomatic expressions and lexical collocations. The learners uttered even novel collocations understandably by mixing them from both the source and target language. It could be said that they were creative in using the language at syntactic, lexical and pragmatic levels. These findings in this study appear to support socio-cultural (Van Lier, 2004), socio-cognitive (Atkinson, 2011; Lantolf, 2011) and socio-ecological views (Kramsch, 2002; Larsen-Freeman, 2002; Kramsch and Stfeensen, 2007; Atkinson, 2011). The target language productions in this study showed significant variations dissimilar to the target language although these findings should not be interpreted in the way that their production is not comprehensible or lacking in providing effective communication. Rather, as Bayley (2005) discussed, these inter-language variations might refer to their creativity by both making use of the source language and forming a new separate and independent linguistic system (Selinker, 1972). Bayley (2005: 9) states that 'second language studies that combine variationist and ethnographic methods have the potential to provide a better understanding of the development of learner competence over time.' Similarly, Mougeon and Rehner (2001) noted that variations in a target language should not be perceived as deviant or incomprehensible. Instead, they might refer to a rich linguistic system that brings novel constructions that provide comprehensible production. However, some findings from neurobiology offer a different perspective. Ullmann (2015) noted that procedural and declarative knowledge may refer to two distinct systems in learning. While procedural knowledge refers to a subconscious and automatic process, declarative knowledge entails conscious learning. Despite this distinction, Ellis (1985) maintained that variation could be viewed as a part of the linguistic competence of L2 learners while Tarone (1990) similarly noted that the competence/performance dichotomy is obsolete. The oral production of the participants in this study showed variations, various constructions as well as standard Turkey Turkish uses, which refers to the fact that linguistic competence might be attained by reinterpreting the target language in different forms and meanings in quite a comprehensible way. 


\section{Conclusion}

This study showed that the target language could be acquired at a later age when the socio-ecological setting is convenient for learners. Various constructions produced by the participants indicated that second language acquisition is not expected to proceed in one direction in any strict manner. For learners, a target language might consist of multi-layers emerging with certain and different constructions dissimilar to the source language. Insistence on strict norms in the target language might lead researchers to interpret oral production within strict limitations. Rather, these variations refer to richness of minds, bodies and worlds. In addition to pure psychologically and biologically driven behavioristic approaches based on positivistic postulates, culturally and socially embodied contexts might also have meaning in second language acquisition studies concerning adult learners.

\section{References}

Abdullahi-Idiagbon, M. S., \& Olaniyi, O. K. (2011). Coinages in Nigerian English: A sociolinguistic perspective. African Nebula, 3, 78-85.

Adjemian, C. (1976). On the nature of inter-language systems. Language Learning, 26, 297-320. https://doi.org/10.1111/j.1467-1770.1976.tb00279.x

Atkinson, D. (2011). A sociocognitive to approach to second language acquisition: How mind, body, and world work together in learning additional languages. In D. Atkinson (Ed.), Alternative approaches to second language acquisition (pp. 143-166). London: Routledge.

Bardovi-Harlig, K. (1999). Researching method. In L. F. Bouton (Ed.), Pragmatics and language learning (Vol. 8, pp. 237-264). Urbana-Champaign: Division of English as an International Language, University of Illinois at UrbanaChampaign.

Bayley, R. (1994). Inter-language variation and the quantitative paradigm: Past-tense marking in Chinese-English. In Elaine Tarone, Susan M. Gass, and Andrew Cohen, eds., Research methodology in second-language acquisition (pp. 157-181). Hillsdale, NJ: Lawrence Erlbaum.

Bayley, R. (2005). Second language acquisition and sociolinguistic variation. Intercultural communication studies, 14(2), 1-15.

Brown, H. D. (2000). Principles of language learning and teaching. (2 nd ed.). White Plains, NY: Longman.

Carter, R. (1998). Vocabulary: Applied linguistics perspectives. London: Routledge. https://doi.org/10.4324/9780203270110

Cook, V. (1997). Monolingual bias in second language acquisition research. Revista Canaria de Estudios Ingleses, 34, 35-49.

Corder, S. P. (1971). Idiosyncratic dialects and error analysis. IRAL-International Review of Applied Linguistics in Language Teaching, 9(2), 147-160. https://doi.org/10.1515/iral.1971.9.2.147

Cresswell, J. W., Plano Clark, V. L., Gutmann, M. L., \& Hanson, W. E. (2003). Advanced mixed methods research designs. In A. Tashakkori \& C. Teddlie (Eds.), Handbook of mixed methods in social and behavioral research. Thousands Oaks, Calif.: Sage.

Dörnyei, Z. (2007). Research methods in applied linguistics. Quantitative, qualitative and mixed methodologies. New York: Oxford University Press.

Ellis, R. (1985). Sources of variability in inter-language. Applied Linguistics, 6, 118-131. https://doi.org/10.1093/applin/6.2.118

Flynn, S. (1987). A parameter-setting model of L2 acquisition. Dordrecht: Reidel. https://doi.org/10.1007/978-94-009-3747-5

Gass, S. M. (2013). Second language acquisition: An introductory course. Routledge.

Hymes, D. H. (1972). Models of the interaction of language and social life. In J. J. Gumperz and D. Hymes (Eds.), Directions in sociolinguistics: The ethnography of communication (pp. 35-71). New York: Holt, Rinehart \& Winston.

James, C. (1980). Contrastive Analysis. London: Longman.

Johnson, J. S., \& Newport, E. L. (1989). Critical period effects in second language learning: The influence of maturational state on the acquisition of English as a second language. Cognitive Psychology, 21, 60-99. https://doi.org/10.1016/0010-0285(89)90003-0 
Johnson, J. S., \& Newport, E. L. (1991). Critical period effects on universal properties of language: The status of subjacency in the acquisition of a second language. Cognition, 39, 215- 258. https://doi.org/10.1016/0010-0277(91)90054-8

Klein, W., \& Perdue, C. (1997). The Basic Variety (or: Couldn't natural languages be much simpler?). Second Language Research , 13, 301-347. https://doi.org/10.1191/026765897666879396

Kramsch, C. (Ed.). (2002). Language acquisition and language socialization: Ecological perspectives. London: Continuum.

Kramsch, C., \& Steffensen, S. V. (2008). Ecological perspectives on second language acquisition and socialization. In P. A. Duff \& N. H. Hornberger (Eds.), Encyclopedia of language and education: Language socialization (pp.17-28). Berlin: Springer Verlag. https://doi.org/10.1007/978-0-387-30424-3_194

Krashen, S. (1982). Principles and Practice in Second Language Acquisition. Oxford: Pergamon Press.

Lado, R. (1957). Linguistics across Cultures: Applied Linguistics for Language Teachers. Ann Arbor: University of Michigan Press.

Lantolf, J. P. (2011). The sociocultural approach to second language acquisition: Sociocultural theory, second language acquisition, and artificial L2 development. In D. Atkinson (Ed.), Alternative approaches to second language acquisition (pp. 24-47). London: Routledge.

Larsen-Freeman, D. (1997). Chaos/complexity science and second language acquisition. Applied Linguistics, 18(2), 141-165. https://doi.org/10.1093/applin/18.2.141

Larsen-Freeman, D. (2002). Language acquisition and language use from a chaos/complexity theory perspective. In C. Kramsch (Ed.), Language acquisition and language socialization (pp.33-46). London: Continuum.

Lenneberg, E. (1967). Biological foundations of language. New York: Wiley.

Marinova - Todd, S. H., Marshall, D. B., \& Snow, C. E. (2000). Three misconceptions about age and L2 learning. TESOL Quarterly, 34(1), 9-34. https://doi.org/10.2307/3588095

Meisel, J. M., Clahsen, H., \& Pienemann, M. (1981). On determining developmental stages in natural second language acquisition. Studies in Second Language Acquisition, 3, 109-135. https://doi.org/10.1017/S0272263100004137

Mougeon, R., \& Rehner, K. (2001). Variation in the spoken French of Ontario French immersion students: The case of juste vs seulement vs rien que.Modern Language Journal, 85(3), 398-415. https://doi.org/10.1111/0026-7902.00116

Nemser, W. (1971). Approximative systems of foreign language learners. IRAL-International Review of Applied Linguistics in Language Teaching, 9(2), 115-124. https://doi.org/10.1515/iral.1971.9.2.115

Özezen, M. Y. (2003, May). Verb roots transferred from Turkish to Çukurova Arabic. 1st International Symposium on Spoken Arabic Dialects and their Oral Literature in Turkey, 17-19 May, Mardin, Turkey.

Patkowski, M. S. (1990). Age and accent in a second language: a reply to James Emil Flege. Applied Linguistics, 11, 73-89. https://doi.org/10.1093/applin/11.1.73

Penfield, W., \& Roberts, L. (1959). Speech and brain-mechanisms. Princeton, NJ: Princeton University Press.

Schumann, J. H. (1978). The pidginization process: A model for second language acquisition. Massachusetts: Newbury House Publishers Inc.

Schumann, J. H. (1986). Research on the acculturation model for second language acquisition. Journal of Multilingual and Multicultural Development, 7, 379-392. https://doi.org/10.1080/01434632.1986.9994254

Selinker L. (1972). Inter-language. International Review of Applied Linguistics, 10, $209-241$.

Slavoff, G. R., \& Johnson, J. S. (1995). The effects of age on the rate of learning a second language. Studies in Second Language Acquisition, 17(01), 1-16. https://doi.org/10.1017/S0272263100013723

Song, J. J. (2002). Linguistic typology and language acquisition: The accessibility hierarchy and relative clauses. Language Research-Seoul-, 38(2), 729-756.

Tarone E. (1983). On the Variability of Inter-language Systems. Applied Linguistics, 15, 285-295.

Tarone, E. (1990). On variation in inter-language: A response to Gregg. Applied Linguistics, 11, 392-400. https://doi.org/10.1093/applin/11.4.392

Towell, R., \& Hawkins, R. (1994). Approaches to second language acquisition. Clevedon, UK: Multilingual Matters. 
Trettenbrein, P. C. (2015). The "grammar" in Universal Grammar: A biolinguistic clarification. Questions and Answers in Linguistics, 2(1), 1-10. https://doi.org/10.1515/qal-2015-0005

Ullman, M. T. (2015). The declarative/procedural model: a neurobiological model of language learning, knowledge and use. Hickok, G., Small, SA (Eds.), The Neurobiology of Language. Elsevier, San Diego, CA.

van Lier, L. (2004). The ecology and semiotics of language learning. Dordrecht: Kluwer Academic Publishers. https://doi.org/10.1007/1-4020-7912-5

Vygotsky, L. S. (1962). Thought and language (E. Hanfmann \& G. Vakar, Eds. and Trans.). Cambridge, MA: MIT Press. https://doi.org/10.1037/11193-000

White, L. (1989): Universal grammar and second language acquisition. Amsterdam: John Benjamins. https://doi.org/10.1075/lald.1

White, L. (1990). Second language acquisition and universal grammar. Studies in second language acquisition, 12, 121-133. https://doi.org/10.1017/S0272263100009049

White, L., \& Genesee, F. (1996). How native is near-native? The issue of ultimate attainment in adult second language acquisition. Second language research, 12(3), 233-265. https://doi.org/10.1177/026765839601200301

Whitehead, T. L. (2005). Basic classical ethnographic research methods. Ethnographically Informed community and Cultural Assessment Research Systems: Working Paper Series. College Park, Maryland: Cultural Ecology of Health and Change.

This work is licensed under a Creative Commons Attribution 3.0 License. 